\title{
Assessing Volatilities of Monetary Policy and their Effects on the Islamic and Conventional Stock Markets in Indonesia
}

\author{
M. Shabri Abd. Majid
}

\begin{abstract}
The main objective of this study is to empirically assess the volatilities of the monetary policy instruments and their effects on the Indonesian Islamic and conventional stock markets. The changes in exchange rate, interest rates, and money supply and their effects on the stock markets are investigated using the Generalized Autoregressive Conditional Heteroskedasticity (GARCH) frameworks. As a big-open economy, the capital market of Indonesia is vulnerable to the global monetary shocks, thus the US federal funds rate is also incorporated into the GARCH model. The study documented that, with the exception of the US interest rate, the volatilities of all monetary policy variables of interest rate, exchange rate, and money supply were documented affecting the volatilities of both Islamic and conventional stock markets. These findings imply that the volatilities of Islamic and conventional stock markets have similar determinants, thus to stabilize the markets, the investigated monetary policy variables should be controlled for by the policy-makers. Any monetary policy design imposed by the policy-makers would have a similar effect on both conventional and Islamic stocks in Indonesia.
\end{abstract}

Keywords: volatility, Islamic vs. conventional stocks, monetary policy, GARCH.

\begin{abstract}
Abstrak
Tujuan utama dari penelitian ini adalah untuk memprediksi secara empiris volatilitas instrumen kebijakan moneter dan pengaruhnya terhadap pasar saham syariah dan konvensional di Indonesia. Perubahan nilai tukar, suku bunga, dan jumlah uang beredar dan pengaruhnya terhadap pasar saham diuji dengan menggunakan menggunakan model Generalized Autoregressive Heteroskedasticity (GARCH). Sebagai negara yang menganut sistem ekonomi terbuka yang pasar modalnya rentan terhadap guncangan moneter global, maka tingkat suku bunga negara Amerika Serikat juga dimasukkan ke dalam model GARCH. Penelitian ini mendokumentasikan bahwa, kecuali suku bunga Amerika Serikat, volatilitas semua variabel kebijakan moneter yang terdiri dari suku bunga, nilai tukar, dan jumlah uang beredar ditemukan berpegaruh signiffkan terhadap volatilitas pasar saham syariah dan konvensional. Temuan ini menunjukkan bahwa volatilitas pasar saham syariah dan konvensional memiliki faktor penentu yang sama. Dalam menstabilkan pasar saham, variabel kebijakan moneter harus dikendalikan oleh pembuat kebijakan. Setiap rancangan kebijakan moneter yang diterapkan di Indonesia akan memiliki efek yang sama baik terhadap saham konvensional maupun saham syariah.
\end{abstract}

Kata Kunci: volatilitas, saham syariah vs. konvensional, kebijakan moneter, GARCH.

\section{How to Cite:}

Majid, M. S. A. (2018). Assesing Volatilities of Monetary Policy and their Effects on the Islamic and Conventional Stock Markets in Indonesia. Signifikan: Jurnal Ilmu Ekonomi. Vol. 7 (2): 161 - 172. doi: http// dx.doi.org/10.15408/sjie.v7i2.7352. 


\section{Introduction}

Exploring stock market volatility and its determinants have proven somewhat tricky due to several perplexing factors. Previous studies on this issue have documented mixed findings. For example, the Islamic stock market of Malaysia is found to be free from interest rate (Yusof and Majid, 2006, 2007), while the Islamic stock market of Indonesia found to be based on the interest rate (Pratama and Azzis, 2017). Additionally, the volatility of Islamic stock market of Malaysia was influenced only by the economic growth and exchange rate (Yusof and Majid, 2006, 2007). Meanwhile, the Islamic stock market in Indonesia is affected by the inflation rate, exchange rate, and global Islamic stocks (Pratama and Azzis, 2017). These different empirical findings quest for further intensive research to ensure robust evidence on the stock market volatility-monetary policy determinants relation, thus the concrete policy recommendation could be forwarded to stabilize and promote the Islamic stock market worldwide.

This study intends to contribute to this debate by empirically assessing the relationship between volatilities of monetary policy variables and both Islamic and conventional stock markets in Indonesia. As the biggest Muslim populous country in the world, Indonesia is a good choice for the study due to its highest potentials to become an international financial hub for the Islamic capital market. This is not an impossible aspiration because the government of Indonesia has shown a strong interest in adopting widely the Islamic economic system into the existing conventional system.

Indonesia is the country, which has the largest number of Islamic financial institutions globally amounting to more than 5.000 institutions. It comprises 34 Islamic banks, 58 Islamic insurances (takaful), 7 Islamic mutual funds, 163 Islamic microfinance institutions, and about 4.500 to 5.500 Islamic co-operative institutions, Baitul Maal wat Tamwil, and Islamic pawnbrokers. To further promote the Islamic financial institutions in the country, the government has launched the first Shari'ah Online Trading System (SOTS) in the world in 2011. The 5.3\% share of Islamic financial market in the year of 2016 is expected to increase and able to catch up the share of Islamic financial markets of Saudi Arab (51.1\%), Malaysia (23.8\%), and United Arab Emirates (19.6\%) (Bappenas, 2017).

For this purpose, the government has officially formed the National Shari'ah Financial Committee (NSFC), regulated by the Presidential Decree, No. 91 (2016). The President and Vice President with the Steering Committee consisting of four ministries, Commissioners of Financial Services Authority and Deposit Insurance Corporation, Bank Indonesia, and the Indonesian Ulema Council directly lead this committee. The establishment of the NSFC is a form of government serious commitment to build Indonesia as one the international Islamic financial hubs worldwide. Thus, addressing the questions to which extent the monetary policy is able to stabilize the Islamic and conventional stock markets volatilities and the to which extent the volatility in the global monetary policy transmitted to the Indonesian stock markets is seen as the important issue and it is timely to be researched for, as its finding provides crucial policy recommendation to promote the Islamic stock market in the country, apart from the existing government efforts by setting up the SOTS and NSFC.

Previous studies on the stock market volatility-economic volatility relation have used three major theories for their explanation. The first one is the Simple Discounted Present 
Value Model. Based on this model, the stock prices are influenced by the firms' future cash flow and the discounted rates. The volatilities in these two factors are determined by macroeconomic variables' volatility, which in turns affects the volatility of stock market (Ibrahim, 2002). This shows that a change in the macroeconomic conditions would cause the stock returns to become volatile, presuming that there are no changes in discount rate.

The second theory explaining the stock market volatility-economic volatility relationship is the Capital Asset Pricing Model (CAPM). This theory is useful in explaining the extent of an asset's risk premium, the risk-free interest rate, and the expected returns of assets' differences (Mishkin and Eakins, 2006). Additionally, according to the CAPM, the risk-free interest rate component is affected by the money supply and thus influencing the financial assets' expected return. Consequently, changes in monetary instruments would also cause the financial asset's expected return to change (Rose, 2000). Meanwhile, the final theory that explains the relationship between volatilities of the stock market and macroeconomic variables is the Arbitraging Pricing Theory (APT). To this theory, the macroeconomic variables compose an essential set of information that affects stock prices (Humpe and Macmillan, 2009).

There have been many studies investigated the importance of monetary policy in regulating the volatilities of stock markets internationally. For example, Hammoudeh and $\mathrm{Li}$ (2008) examined the volatility of the Arab stock markets and their impacts to the estimated volatility persistence over the period 1994 to 2001 and found the contradicting findings to the Aggarwal et al. (1999), where the Gulf Arab stocks were more responsive to major international events than to the domestic and regional shocks. Zakaria and Shamsuddin (2012) found a modest significant effect of macroeconomic volatilities on the stock returns in Malaysia, and it was highly persistent and positively correlated to the expected stock returns in the Khartoum Stock Exchange (Ahmed and Suliman, 2011; Ahmed et al, 2016) and the Islamic stocks have a higher volatility during the 2008 global crisis than their conventional counterparts (Romli et al., 2012). Similarly, the Malaysian Islamic banks were also affected by the 1997 Asian economic crisis and 2007 global crisis (Kassim and Majid, 2010).

Recently, there has been an increased interest in researching the trends of Islamic stock markets and their macroeconomic determinants worldwide. As for the Islamic stock market in Malaysia, the conditional volatilities of conventional and Islamic stock markets and their relations to the volatilities of monetary instruments have been explored using the GARCHMean (Yusof and Majid, 2006) and GARCH $(1,1)$ within the Vector Autoregressive (VAR) framework (Yusof and Majid, 2007) over the period 1992 - 2000. They found that the volatility in interest rate only affected the conventional stock market, but it did not affect the volatility of Islamic stocks. Meanwhile, Hammoudeh and Li (2008) examined the sudden changes in the volatility of the Arab stock markets and their impacts to the estimated volatility persistence using the Iterated Cumulative Sums of Squares (ICSS) over the period 1994 to 2001. In contrast to the findings in the emerging markets by Aggarwal et al. (1999), they found that majority of the Gulf Arab stocks were more responsive to major international events than to the domestic and regional shocks. For example, the 1997 Asian crisis and the September $11^{\text {th }}, 2001$ attack have constantly affected the Arab markets.

Majid and Yusof (2009) further explored the extent to which the macroeconomic 
determinants caused the Islamic equity market of Malaysia to change and documented that both changes in the domestic and the US monetary instruments impacted the Islamic stocks in the long run. This finding is in harmony with the study by Zakaria and Shamsuddin (2012) who documented a modest support on the presence of the stock returns-macroeconomic volatility relation.

Furthermore, Kassim and Majid (2010) and Romli et al. (2012) assessed empirically the impact of the 1997 Asian economic crisis and 2007 global crisis on the Islamic and conventional stock markets in Malaysia and found that both the Islamic and conventional banks were susceptible to financial shocks and the Islamic stocks have a higher volatility than their conventional counterparts. Ahmed and Suliman (2011) revealed that the conditional volatility of the Khartoum Stock Exchange (KSE) was highly persistent and positively correlated to the expected stock returns over the 2008 economic crisis period. Similarly, Dewandaru et al. (2014) and Saadaoui and Boujelbene (2015) found that the co-movements between the Islamic and conventional equity markets during the major crises were spread through excessive linkages, implying that the crisis has affected all financial assets, both Islamic and conventional. However, the US was weakly correlated to the Islamic emerging markets (Majdoub and Mansour, 2014), the Islamic stock market of Malaysia was independent from the changes in interest rate (Yusof and Majid, 2006; 2007), and thus the Islamic stocks were relatively immune to the changes in interest rates as compared to their conventional counterparts (Shamsuddin, 2014). These findings contradicted the widespread beliefs that due to its interest-free nature, the Islamic banking system is sheltered from the economic shocks.

In the context of Indonesia, both short-and long-run relationship between macroeconomic determinants and Islamic stocks using Vector Error Correction Model (VECM) (Antonio et al, 2013) and variance decompositions (Majid, 2016) techniques, found that inflation, money supply, exchange rate, and crude oil price significantly affected the Islamic stocks, showing the importance of these macroeconomic determinants to be focused on when stabilizing Islamic stock markets in the country. As for measuring the volatilities of Islamic stock markets, in his simple study using only the Time Series Plots and Histogram, Tanjung (2014) found that the Jakarta Islamic Index (JII) was abnormally distributed. Meanwhile, by using the GARCH model, Pratama and Azzis (2017) documented that the interest rate, exchange rate, global DJI indices of the UK and Malaysia affected the volatility of Jakarta Islamic stock returns, while the inflation rate, the DJI indices of the US and Japan were not.

Unlike the studies by Tanjung (2014) who only measured the volatility of Islamic stock market using a very simple statistical analysis and did not investigate the causes of the volatilities of Islamic stocks and the study by Pratama and Azzis (2017) who only investigated the impact of volatility of monetary variables on the Islamic stock market, and did not compared it to the conventional stock market, this study empirically and comparatively assesses the impacts of monetary policy variables on both Islamic and conventional stocks in Indonesia using the standardized estimation model of volatility, GARCH. Additionally, the study by Pratama and Azzis (2017) did not specify the period of investigation and did not incorporate the leading global monetary policy variable into their analysis. Considering Indonesia as the biggest open- economy, which is susceptible to the changes in the global 
monetary policy, this study incorporated the federal funds rate (FFR) of the US into the analysis. Thus, this study, specifically, aims to empirically assess the volatilities of monetary policy variables and their effects on both Islamic and conventional stock markets in the biggest Muslim populous country, Indonesia.

Having the above novelties, findings of this study are hoped to shed some lights for investors to design a proper trading strategies and for policy makers to formulate a prudent and an effective monetary strategies to promote the Islamic stock market, as the country seriously aspires to adopt Islamic finance become an integrated part of the existing conventional economic system.

\section{Method}

This study uses the standard Generalized Autoregressive Conditional HeteroskedasticityMean (GARCH-M) to assess the predictive power of volatilities of monetary policy variables on both conventional and Islamic stock markets. The model of Autoregressive Conditional Heteroskedasticity $(\mathrm{ARCH})$ has an important role in finance as it explains the direct association of variance and risk as well as risk-return trade-off (Bollerslev et al., 1992). The ARCH-M Model enables to estimate a linear relationship between conditional mean and conditional variance with the following equation:

$$
y_{t}=g\left(x_{t-1,} \sigma_{t}^{2}, b\right)+\varepsilon_{t}
$$

The Equation (1) shows an association between the conditional variance and conditional mean of $y_{t}$, depending on the sign of the partial derivative of $\mathrm{g}\left(x_{t-1,} \sigma_{t}^{2}, b\right)$ with respect to $\sigma_{t}^{2}$. This model is suitable for the purpose of our study as many financial theories involve an explicit risk-return trade-off. Stocks with higher expected risk ought to offer higher rates of return, implying that an increase in the conditional variance must be associated with increases in the conditional mean.

Following Muradoglu et al. (1999) and Yusof and Majid (2006; 2007), the Equation (1) can be re-written in the form of the standard GARCH-M (p,q) to explain the changes in the expected returns, as follows:

$$
\begin{aligned}
& R_{t}=\sum_{i=1}^{m} \alpha_{i} R_{t-i}+\lambda_{i} h_{t}+\varepsilon_{t} \\
& h^{2}{ }_{t}=\beta_{0}+\beta_{1} \varepsilon^{2}{ }_{t-1}+\beta_{2} h^{2}{ }_{t-1}
\end{aligned}
$$

where $R_{t}$ represents stock returns, $h_{t}$ is the risk, $\varepsilon$ is the error term, $t$ is the time, and $m$ is the lag order of the autoregressive process. The restrictions of $\beta_{0}>0, \beta_{1} \geq 0$, and $\beta_{2} \geq 0$ are imposed to ensure the positive value of conditional variance, $h^{2}$. Additionally, $\lambda$ is the risk of market price, and $h_{t}$ is the market risk premium for expected volatility, thus the estimated coefficient of $\lambda$ shows the index of a relative risk aversion. A positive $\lambda$ implies the risk-return trade-off. The $\varepsilon_{t}$ is assumed to have error distribution with zero mean and the $h_{t}^{2}$ variance, where $h_{t}$ is used to measure volatility. Equation (3.3) shows that the conditional variance, $h_{t}^{2}$ is also influenced by the past values of the stock returns' error terms, $\varepsilon_{t-1}^{2}$ and its own lagged value of $h_{t-1}^{2}$

Referring to Choudhury (1996), if the estimated $\beta_{1}+\beta_{2}=1$, it implies the persistence of forecast of the conditional variance over all finite horizons and an infinite variance for the unconditional distribution of $\varepsilon_{t}$. If the estimated $\beta_{1}+\beta_{2}<1$, it shows the covariance stationary of 
$\varepsilon_{t}$ Thus, the closer the value of persistence measure $\left(\beta_{1}+\beta_{2}\right)$ to unity, the slower would be the decay rate. The GARCH-M $(1,1)$ model is adopted in this study since the low orders for the lag length 1 is sufficient to model the variance dynamics for the purpose of our study. Many empirical studies indicated that GARCH $(1,1)$ model adequately fits to estimate the stock return series (Bollerslev, 1986; Akgiray, 1989; Bollerslev et al., 1992; and Liljeblom and Stenius, 1997).

To assess the effects of volatilities of monetary policy on both Islamic and conventional stock markets, the Equations (2) and (3) are modified by incorporating the set of monetary policy variables $(X)$, as follows:

$$
\begin{aligned}
& R_{t}=\sum_{i=1}^{m} \alpha_{i} R_{t-1}+\lambda h_{t}+\phi X_{t}+\varepsilon_{t} \\
& h_{t}^{2}=\beta_{0}+\beta_{1 t-1}^{2}+\beta_{2} h_{t-1}^{2}+\phi X_{t}
\end{aligned}
$$

where $X_{t}$ is the monetary policy variables comprises money supply, interest rate, exchange rate, and the US federal funds rate. Since each of the monetary variables enters the equation one by one, thus the contribution of each monetary policy variable to the stock returns behaviour could be easily observed.

To provide robust findings, the study utilizes monthly data spanning from 1999 to 2015. Jakarta Islamic Index (JII) and Jakarta Composite Index (JCI) are used to measure the volatilities in the Islamic and conventional stock markets, while the monetary policy variables of the money supply, interest rate, and exchange rate are utilized. The money supply (M2) is used as the money supply (MS) variable and is expressed in the domestic currency, i.e. Indonesian Rupiah (IDR). The exchange rate (EXR) is measured by the nominal effective exchange rate, the bilateral exchange rate with reference to the US dollar. The interest rate (INR) is measured by the Indonesian Bank interest rate. To capture the effect of international monetary changes on the stock markets, the Federal Funds Rate (FFR) of the US is also utilized. Except for INR and FFR, the data for MS and EXR are transformed into the natural logarithmic form. These data are obtained from the International Financial Statistics (IFS) Database of International Monetary Fund (IMF) and complemented by data from www.econstats.com, and Yahoo finance website.

\section{Result and Discussion}

The section provides and discusses the findings of the study based on the GARCH $(1,1)$ and GARCH-M models to highlight relationships between volatilities of the monetary policy variables and volatilities of both Islamic and conational stock returns as well as their volatilities' persistence. Table 1 reports the findings from the GARCH $(1,1)$ model based on the Equations (1) and (2). Apart from reporting the estimated coefficients from the GARCH $(1,1)$, Table 1 also reports the statistical tests of skewness, kurtosis, autocorrelation using the Ljung -Box Q and the Durbin-Watson Statistics tests for autocorrelation, and Jarque-Bera test for normality. The model passes the classical assumption tests of normality, non-autocorrelation of data. In estimating the model, the study sets the order of the autoregressive process at lag $(m)$ equal to 1. The uses of $m=1,2, \ldots, 6$ are also tested through Correlogram Q-statistics and the ARCH-LM test and found that the presence of autocorrelation could be eliminated at the lag equal to 1 .

As observed from Table 1, the estimated coefficients for the lagged values of the squared 
residuals and the lagged value of the conditional variance are positive for both Islamic and conventional stock markets in Indonesia. The summation of the coefficients for the lagged values of the squared residuals in the variance equation and the lagged value of the conditional variance are 0.966 and 0.978 , and according to Bollerslev (1986), this shows the non-explosiveness of the estimated conditional variances. The estimated $\beta_{1}$ is found to be significant for the conventional stock market, but insignificance for the Islamic stock market. This indicates the existence of cluster volatility in the conventional stock returns, but not in the Islamic stock returns.

Table 1. Predicting volatilities of the Islamic and conventional stock returns based on the GARCH $(1,1)$ Model

\begin{tabular}{|c|c|c|}
\hline \multirow{2}{*}{ Estimated Coefficient } & \multicolumn{2}{|c|}{ Stock Returns } \\
\hline & Conventional & Islamic \\
\hline$a_{1}$ & $0.011(0.821)$ & 0.017 (0.932) \\
\hline 1 & $-0.015(0.678)$ & $-0.001(0.989)$ \\
\hline$\lambda_{1}$ & $0.148(0.398)$ & $0.086(0.685)$ \\
\hline$\beta_{0}$ & $0.0017(0.354)$ & $0.0009(0.467)$ \\
\hline$\beta_{1}$ & $0.465(0.081)$ & $0.357(0.231)$ \\
\hline$\beta_{2}$ & $0.501(0.000)$ & $0.621(0.000)$ \\
\hline Skewness & 0.121 & -0.107 \\
\hline Kurtosis & 3.743 & 3.986 \\
\hline Jarque-Bera & 9.612 & 6.876 \\
\hline Ljung-Box Q(6) & $18.132(0.211)$ & $11.717(0.552)$ \\
\hline Ljung-Box Q(12) & $31.212(0.232)$ & $18.976(0.779)$ \\
\hline Ljung-Box Q(24) & $42.132(0.437)$ & $24.545(0.912)$ \\
\hline$\left(\beta_{1}+\beta_{2}\right)$ & 0.966 & 0.978 \\
\hline Durbin-Watson & 1.909 & 1.917 \\
\hline \multirow{2}{*}{ ARCH LM } & $\begin{array}{c}\text { F-stats: } \\
0.567(0.833)\end{array}$ & $\begin{array}{c}\text { F-stats: } \\
0.872(0.587)\end{array}$ \\
\hline & $\begin{array}{l}\text { Observed-R2: } \\
3.243(0.787)\end{array}$ & $\begin{array}{l}\text { Observed-R2: } \\
5.765(0.698)\end{array}$ \\
\hline
\end{tabular}

Note: The figures in parentheses (.) indicate the $p$-value. Obs* $R^{2}=$ the observed $R^{2}, L-B=$ the Ljung-Box $Q$ test, $D-W=$ the Durbin-Watson test, ARCH-LM = the Autoregressive Conditional Heteroskedasticity-Lagrange Multiplier test.

To check for model robustness, the tests on the residuals that are produced using the GARCH-M model are further conducted. In this study, the existence of the predicted residuals is tested using the Ljung-Box Q Statistics for lags of 6, 12 and 24. The study finds the null hypothesis of the presence of no autocorrelation could not be rejected even at the $10 \%$ level. These findings confirm that the mean equation is rightly specified for both conventional and Islamic stock returns. The ARCH LM estimation with all lags shows that the ARCH effect could be eliminated.

Furthermore, the study finds that the risk, as calculated by the conditional standard deviation, has an insignificant impact on the stock returns. The positive sign of the estimated coefficient suggests that higher risk leads to higher returns, finding in harmony with the presence of risk-return trade-off. Thus, this study finds no significant evidence of the presence of time-varying risk premium for both Islamic and conventional stock returns. The absence of the risk-return trade-off both in the Islamic and conventional stock markets in Indonesia supported by the earlier studies on the stock markets of Greece, Argentina, India, Thailand, Mexico, and Zimbabwe over the 1976-1994 period (Choudhury, 1996), Turkey (Muradoglu et al., 1999), and the UK (Poon and Taylor, 1992). 
Signifikan: Jurnal Ilmu Ekonomi

Volume 7 (2), 2018: 161 - 172

Table 2. Volatilities of monetary policy variables and their effects on the Islamic and conventional stock returns based on the GARCH-M model

\begin{tabular}{|c|c|c|c|c|c|c|c|c|}
\hline \multirow{2}{*}{ Variable } & \multicolumn{4}{|c|}{ Conventional Stock Market } & \multicolumn{4}{|c|}{ Islamic Stock Market } \\
\hline & MS & INR & EXR & FFR & MS & INR & EXR & FFR \\
\hline$a_{1}$ & $\begin{array}{r}0.004 \\
(0.976)\end{array}$ & $\begin{array}{r}0.013 \\
(0.908)\end{array}$ & $\begin{array}{r}-0.016 \\
(0.800)\end{array}$ & $\begin{array}{l}-0.054 \\
(0.798)\end{array}$ & $\begin{array}{r}0.007 \\
(0.909)\end{array}$ & $\begin{array}{r}0.017 \\
(0.907)\end{array}$ & $\begin{array}{c}-0.019 \\
(0.809)\end{array}$ & $\begin{array}{l}-0.035 \\
(0.789)\end{array}$ \\
\hline$\delta_{1}$ & $\begin{array}{r}-0.004 \\
(0.794)\end{array}$ & $\begin{array}{r}-0.012 \\
(0.676)\end{array}$ & $\begin{array}{r}0.008 \\
(0.843)\end{array}$ & $\begin{array}{r}0.004 \\
(0.807)\end{array}$ & $\begin{array}{r}-0.005 \\
(0.876)\end{array}$ & $\begin{array}{r}-0.015 \\
(0.688)\end{array}$ & $\begin{array}{r}0.007 \\
(0.823)\end{array}$ & $\begin{array}{r}0.005 \\
(0.883)\end{array}$ \\
\hline$\lambda$ & $\begin{array}{r}0.141 \\
(0.308)\end{array}$ & $\begin{array}{r}0.128 \\
(0.302)\end{array}$ & $\begin{array}{r}0.043 \\
(0.587)\end{array}$ & $\begin{array}{r}0.134 \\
(0.398)\end{array}$ & $\begin{array}{r}0.108 \\
(0.377)\end{array}$ & $\begin{array}{r}0.126 \\
(0.331)\end{array}$ & $\begin{array}{r}0.071 \\
(0.560)\end{array}$ & $\begin{array}{r}0.129 \\
(0.393)\end{array}$ \\
\hline$\varphi$ & $\begin{array}{l}-0.308 \\
(0.504)\end{array}$ & $\begin{array}{l}-0.031 \\
(0.149)\end{array}$ & $\begin{array}{l}-0.837 \\
(0.035)\end{array}$ & $\begin{array}{l}-0.108 \\
(0.058)\end{array}$ & $\begin{array}{l}-0.308 \\
(0.504)\end{array}$ & $\begin{array}{l}-0.031 \\
(0.149)\end{array}$ & $\begin{array}{c}-0.837 \\
(0.035)\end{array}$ & $\begin{array}{l}-0.108 \\
(0.058)\end{array}$ \\
\hline$\beta_{0}$ & $\begin{array}{l}0.0006 \\
(0.448)\end{array}$ & $\begin{array}{l}0.0008 \\
(0.176)\end{array}$ & $\begin{array}{l}0.0001 \\
(0.359)\end{array}$ & $\begin{array}{l}0.0008 \\
(0.119)\end{array}$ & $\begin{array}{l}0.0006 \\
(0.448)\end{array}$ & $\begin{array}{l}0.0008 \\
(0.176)\end{array}$ & $\begin{array}{l}0.0001 \\
(0.359)\end{array}$ & $\begin{array}{l}0.0008 \\
(0.119)\end{array}$ \\
\hline$\beta_{1}$ & $\begin{array}{r}0.248 \\
(0.198)\end{array}$ & $\begin{array}{r}0.299 \\
(0.132)\end{array}$ & $\begin{array}{r}0.038 \\
(0.543)\end{array}$ & $\begin{array}{r}0.265 \\
(0.334)\end{array}$ & $\begin{array}{r}0.282 \\
(0.189)\end{array}$ & $\begin{array}{r}0.299 \\
(0.176)\end{array}$ & $\begin{array}{r}0.036 \\
(0.376)\end{array}$ & $\begin{array}{r}0.299 \\
(0.183)\end{array}$ \\
\hline$\beta_{2}$ & $\begin{array}{r}0.683 \\
(0.000)\end{array}$ & $\begin{array}{r}0.681 \\
(0.001)\end{array}$ & $\begin{array}{r}0.921 \\
(0.000)\end{array}$ & $\begin{array}{r}0.676 \\
(0.003)\end{array}$ & $\begin{array}{r}0.684 \\
(0.006)\end{array}$ & $\begin{array}{r}0.682 \\
(0.000)\end{array}$ & $\begin{array}{r}0.923 \\
(0.009)\end{array}$ & $\begin{array}{r}0.687 \\
(0.003)\end{array}$ \\
\hline$\phi$ & $\begin{array}{r}0.028 \\
(0.041)\end{array}$ & $\begin{array}{l}-0.064 \\
(0.037)\end{array}$ & $\begin{array}{r}0.085 \\
(0.023)\end{array}$ & $\begin{array}{r}0.006 \\
(0.660)\end{array}$ & $\begin{array}{r}0.037 \\
(0.058)\end{array}$ & $\begin{array}{l}-0.058 \\
(0.073)\end{array}$ & $\begin{array}{r}0.079 \\
(0.012)\end{array}$ & $\begin{array}{r}0.005 \\
(0.612)\end{array}$ \\
\hline Skewness & -0.143 & -0.322 & 0.043 & -0.201 & -0.107 & -0.204 & 0.201 & -0.200 \\
\hline Kurtosis & 3.006 & 3.096 & 3.001 & 3.050 & 3.098 & 3.222 & 3.007 & 3.090 \\
\hline Jarque-Bera & 2.122 & 2.054 & 1.987 & 2.731 & 2.430 & 2.456 & 1.876 & 2.609 \\
\hline$L-B(6)$ & $\begin{array}{r}14.000 \\
(0.21)\end{array}$ & $\begin{array}{l}15.543 \\
(0.278)\end{array}$ & $\begin{array}{l}11.871 \\
(0.410)\end{array}$ & $\begin{array}{l}11.098 \\
(0.577)\end{array}$ & $\begin{array}{l}14.876 \\
(0.287)\end{array}$ & $\begin{array}{l}15.543 \\
(0.276)\end{array}$ & $\begin{array}{l}11.098 \\
(0.409)\end{array}$ & $\begin{array}{l}11.123 \\
(0.543)\end{array}$ \\
\hline $\mathrm{L}-\mathrm{B}(12)$ & $\begin{array}{l}23.543 \\
(0.309)\end{array}$ & $\begin{array}{l}25.777 \\
(0.398)\end{array}$ & $\begin{array}{l}17.502 \\
(0.799)\end{array}$ & $\begin{array}{l}24.609 \\
(0.570)\end{array}$ & $\begin{array}{l}25.008 \\
(0.346)\end{array}$ & $\begin{array}{l}25.098 \\
(0.398)\end{array}$ & $\begin{array}{l}17.321 \\
(0.909)\end{array}$ & $\begin{array}{l}22.098 \\
(0.876)\end{array}$ \\
\hline L-B(24) & $\begin{array}{l}34.987 \\
(0.532)\end{array}$ & $\begin{array}{l}35.009 \\
(0.487)\end{array}$ & $\begin{array}{l}24.900 \\
(0.903)\end{array}$ & $\begin{array}{l}27.096 \\
(0.876)\end{array}$ & $\begin{array}{l}34.567 \\
(0.598)\end{array}$ & $\begin{array}{l}35.001 \\
(0.476)\end{array}$ & $\begin{array}{l}22.045 \\
(0.900)\end{array}$ & $\begin{array}{l}27.012 \\
(0.877)\end{array}$ \\
\hline$\left(\beta_{1}+\beta_{2}\right)$ & 0.931 & 0.960 & 0.959 & 0.941 & 0.966 & 0.981 & 0.959 & 0.986 \\
\hline$D-W$ & 1.962 & 1.998 & 2.012 & 1.999 & 1.987 & 1.995 & 2.030 & 1.969 \\
\hline \multirow{2}{*}{ ARCH-LM } & $\begin{array}{r}\text { F-stats: } \\
1.199 \\
(0.498)\end{array}$ & $\begin{array}{r}\text { F-stats: } \\
0.598 \\
(0.832)\end{array}$ & $\begin{array}{r}\text { F-stats: } \\
2.908 \\
(0.046)\end{array}$ & $\begin{array}{r}\text { F-stats: } \\
0.590 \\
(0.798)\end{array}$ & $\begin{array}{r}\text { F-stats: } \\
1.099 \\
(0.618)\end{array}$ & $\begin{array}{r}\text { F-stats: } \\
0.597 \\
(0.668)\end{array}$ & $\begin{array}{r}\text { F-stats: } \\
2.987 \\
(0.034)\end{array}$ & $\begin{array}{r}\text { F-stats: } \\
0.876 \\
(0.798)\end{array}$ \\
\hline & $\begin{array}{r}\text { Obs }^{*} R^{2}: \\
6.333 \\
(0.487)\end{array}$ & $\begin{array}{r}\text { Obs }^{*} R^{2}: \\
3.876 \\
(0.765)\end{array}$ & $\begin{array}{c}\text { Obs* }{ }^{2} \text { : } \\
15.997 \\
(0.019)\end{array}$ & $\begin{array}{r}\text { Obs }^{*} R^{2}: \\
3.697 \\
(0.777)\end{array}$ & $\begin{array}{r}\text { Obs }^{*} R^{2}: \\
6.164 \\
(0.49)\end{array}$ & $\begin{array}{r}\text { Obs* }^{2}: \\
3.777 \\
(0.700)\end{array}$ & $\begin{array}{c}\text { Obs }^{*} R^{2}: \\
15.898 \\
(0.016)\end{array}$ & $\begin{array}{r}\text { Obs }^{*} R^{2}: \\
3.698 \\
(0.798)\end{array}$ \\
\hline
\end{tabular}

Note: Obs ${ }^{*}{ }^{2}$ = the observed R2 ${ }^{2} \mathrm{~L}-\mathrm{B}=$ the Ljung-Box Q test, $\mathrm{D}-\mathrm{W}=$ the Durbin-Watson test, $A R C H-\mathrm{LM}=$ the Autoregressive Conditional Heteroskedasticity- Lagrange Multiplier test.

From Table 1, findings from the GARCH $(1,1)$ model show the lack of predictive power of standard deviation in describing the volatility of stock returns. Thus, to better model the volatility of the stock returns, the macroeconomic variables should be incorporated in the model (see, for example, Liljeblom and Stenius, 1997; Morelli, 2002). For this purpose, this study predicts the volatilities of monetary policy variables of money supply, domestic and international interest rates, exchange rate and their effects on the Islamic and conventional stock markets using the GARCH-M model. Table 2 reports the findings from the GARCH-M model based on the Equations 4 and 5.

Referring to Table 2, with the exception of the international interest rate of the US, all other variables are documented to have projecting power in describing the volatility of both Islamic and conventional stock returns. This finding supports the model of stock valuation, where the stock prices portray the discounted present values of the future cash flows of the firms. For instance, when the interest rate increases cause the stock prices and, in turns, affects 
the returns to decline. Thus, the investors who seek to minimize risk should be aware of the interest rates' changes. The volatilities in interest rates lead the stock markets to volatile too. This finding implies that to stabilize the stock markets in the country, the policy-makers should control the stability of the interest rate, as one of the monetary instruments. This finding is in line with the studies by Majid and Yusof (2009) on the Malaysian Islamic stock markets, Majid (2016) and Pratama and Azzis (2017) on the Islamic stock market of Indonesia, and Muradoglu et al. (1999) on the Turkish stock market.

The significance of interest in affecting the volatilities of the Islamic stock market further implies that the Indonesian stock market is still influenced by the interest rate. This finding is against the Islamic belief that the interest rate should not affect significantly the stock market volatility. Ideally, the investors should look for beyond the profit maximization when inventing their monies by considering the ethical dimension of their investments (Webley et al, 2001). Thus, the Muslim investors should not consider interest rate as the determining factor when buying the stocks.

Additionally, our finding provides evidence that the Islamic stock market of Indonesia seems to be unable to free themselves totally from the riba-based business activities. This is the widely accepted empirical evidence on the failure of Islamic financial institution to be really Islamic in their operation. For example, Chong and Liu (2009), Khan (2010), Azmat et al. (2015), Yusof (2008) found that the Islamic banking is not totally free from interest. The latest finding by Majeed and Zainab (2017) also found that the Islamic banking in Pakistan has failed to be run totally based on the Islamic principles, which is riba-free.

Furthermore, the Islamic and conventional stock markets' volatility found to be significantly affected by the money supply and exchange rate. The volatilities of stock returns are influenced by the economic performance, thus it is reasonable that changes in the future macroeconomic uncertainty, including the money supply and exchange rate, would cause the stock return to being volatile. The significance of money supply and exchange rate in affecting the stock markets is in harmony with the finding by Majid and Yusof (2009), Yusof and Majid (2006, 2007) on the Malaysian Islamic stock markets, Majid (2016) and Pratama and Azzis (2017) on the Islamic stock market of Indonesia. These findings further imply that in order to promote and enhance the development of both Islamic and conventional stock markets, the Indonesian government authorities should stabilize the money supply and exchange rate from higher volatility.

\section{Conclusion}

This study empirically assessed the volatilities of the monetary policy instruments and their effects on the Indonesian Islamic and conventional stock markets over the period 19992015 using the GARCH $(1,1)$ and GARCH (M) models. The study documented that, with the exception of the US interest rate, the volatilities of all monetary policy variables of interest rate, exchange rate, and money supply were documented affecting the volatilities of both Islamic and conventional stock markets. These findings imply that the volatilities of Islamic and conventional stock markets have similar determinants, thus to stabilize the markets, the volatilities of the money supply, interest rate, and exchange rate should be controlled for by the policy-makers. Since the Indonesian stock market comprises the majority of Islamic 
stocks, thus any monetary policy design imposed by the policy-makers would have a similar effect on both conventional and Islamic stocks in Indonesia.

The findings of this study shed essential policy repercussions for both Islamic and conventional stock markets of Indonesia. When determining their portfolio's investment, the investors should consider the higher volatility persistence with regards to stock returns predictability. As for the policy-makers, to curtail the capital outflows due to higher volatility of the stock returns, the exchange rates, money supply, and interest rates should be controlled for. Imposing mixed monetary policies instruments should also be considered as one of the effective economic policies to curb the capital outflows from the domestic stock markets, thus, in turns, lead to a more volatility of the capital market as well as the national economy.

To produce more convincing and comprehensive evidence on the volatilities of monetary policy variable-stock returns relation, a more rigorous analysis using extensive GARCH models is suggested. A similar study by comparing the volatilities of global Islamic stock markets would also enrich the existing literature on the importance of monetary policy design in stabilizing and promoting the Islamic stock market in the country.

\section{References}

Abdul Rahim, F., Ahmad, N., \& Ahmad, I. (2009). Information Transmission Between Islamic Stock Indices in South East Asia. International Journal of Islamic and Middle Eastern Finance and Management. Vol. 2(1): 7-19. doi: https://doi.org/10.1108/17538390910946 230.

Aggarwal, R., Inclan, C., \& Leal, R. (1999). Volatility in Emerging Stock Markets. Journal of Financial and Quantitative Analysis. Vol. 34(1): 33-55.

Ahmed, A. E. M., \& Suliman, S. Z. (2011). Modeling Stock Market Volatility Using GARCH Models: Evidence From Sudan. International Journal of Business and Social Science. Vol. 2(23): 114-128

Ahmed, F., Awais, I., \& Pervaiz, A. (2016). Modeling Volatility for Conventional and Islamic Stock Market Indices. Journal of Independent Studies \& Research: Management \& Social Sciences \& Economics. Vol. 14(1): 1-2

Akgiray, V. (1989). Conditional heteroscedasticity in Time Series of Stock Returns: Evidence and Forecast. The Journal of Business. Vol. 62(1): 55-80.

Antonio, M. S., Hafidhoh, H., \& Fauzi, H. (2013). The Islamic Capital Market Volatility: a Comparative Study Between Indonesia and Malaysia. Bulletin of Monetary Economics and Banking. Vol. 15(4): 377-400.

Azmat, S., Azad, A. S., Ghaffar, H., \& Bhatti, I. (2015). Why Interest-free Islamic Banking is not Free From Interest?. Working Paper, Deakin University, 1-25.

Bappenas. (2017). Siaran Pers: Komite Nasional Keuangan Syariah untuk Percepatan Pengembangan Ekonomi dan Keuangan Syariah di Indonesia (Press Release: Sharia National Finance Committee for the Acceleration of Shariah Economic and Financial Development in Indonesia). Retrieved from: https://kominfo.go.id/index.php/content/detail/10204/ komite-nasional-keuangan-syariah-untuk-percepatan-pengembangan-ekonomi-dankeuangan-syariah-di-indonesia/0/artikel_gpr 
Bollerslev, T. (1986). Generalized Autoregressive Conditional Heteroskedasticity. Journal of Econometrics. Vol. 31(3): 307-327. doi: https://doi.org/10.1016/0304-4076(86)90063-1.

Bollerslev, T., Chou, R. Y., \& Kroner, K. F. (1992). ARCH Modeling in Finance: A Review of The Theory and Empirical Evidence. Journal of Econometrics. Vol. 52(1-2): 5-59. doi: https://doi.org/10.1016/0304-4076(92)90064-X.

Choudhry, T. (1996). Stock Market Volatility and The Crash of 1987: Evidence From Six Emerging Markets. Journal of International Money and Finance. Vol. 15(6): 969-981. doi: https://doi.org/10.1016/S0261-5606(96)00036-8.

Chong, B. S., \& Liu, M. H. (2009). Islamic Banking: Interest-Free or Interest-Based?. PacificBasin Finance Journal. Vol. 17 (1): 125-144. doi: https://doi.org/10.1061/j. pacfin.2007.12.003.

Dewandaru, G., Rizvi, S. A. R., Masih, R., Masih, M., \& Alhabshi, S. O. (2014). Stock Market Co-movements: Islamic Versus Conventional Equity Indices with MultiTimescales Analysis. Economic Systems. Vol. 38(4): 553-571.

Hammoudeh, S., \& Li, H. (2008). Sudden Changes in Volatility in Emerging Markets: The Case of Gulf Arab Stock Markets. International Review of Financial Analysis. Vol. 17(1): 47-63. doi: https://doi.org/10.1016/S2212-5671(12)00118-9.

Humpe, A., \& Macmillan, P. (2009). Can Macroeconomic Variables Explain Long-term Stock Market Movements? A Comparison of The US and Japan. Applied Financial Economics. Vol. 19(2): 111-119. doi: https://doi.org/10.1080/09603100701748956.

Ibrahim, M. H. (2002). Volatility Interactions Between Stock Returns and Macroeconomic Variables: Malaysian Evidence. Savings and Development. Vol. 26(2): 183-195.

Liljeblom, E., \& Stenius, M. (1997). Macroeconomic Volatility and Stock Market Volatility: Empirical Evidence on Finnish Data. Applied Financial Economics. Vol. 7(4): 419-426. doi: https://doi.org/10.1080/096031097333538.

Kassim, S. H., \& Majid, M. S. A. (2010). Impact of Financial Shocks on Islamic Banks: Malaysian Evidence During 1997 and 2007 Financial Crises. International Journal of Islamic and Middle Eastern Finance and Management. Vol. 3(4): 291-305. doi: https:// doi.org/10.1108/17538391011093243.

Khan, F. (2010). How 'Islamic 'is Islamic banking?. Journal of Economic Behavior \& Organization. Vol. 76(3): 805-820. doi: https://doi.org/10.1016/j.ebo.2010.09.015.

Majdoub, J., \& Mansour, W. (2014). Islamic Equity Market Integration and Volatility Spillover Between Emerging and US Stock Markets. The North American Journal of Economics and Finance. Vol. 29(C): 452-470.

Majeed, M. T., \& Zainab, A. (2017). How Islamic is Islamic banking in Pakistan?. International Journal of Islamic and Middle Eastern Finance and Management. Vol. 10(4): 470-483. doi: https://doi.org/10.1108/IMEFM-03-2017-0083.

Majid, M. S. A. (2016). The Short-run and Long-run Relationship in The Indonesia Islamic Stock Returns. Al-Iqtishad: Jurnal Ilmu Ekonomi Syariah (Journal of Islamic Economics). Vol. 8(1): 1-18. doi: https://doi.org/10.15408/aiq.v8i1.2505.

Majid, M. S. A., \& Yusof, R. M. (2009). Long-run Relationship Between Islamic Stock Returns and Macroeconomic Variables: An Application of The Autoregressive 
Distributed Lag Model. Humanomics. Vol. 25 (2): 127-141. doi: https://doi. org/10.1108/08288660910964193.

Mishkin, F. S., \& Eakins, S. G. (2006). Financial markets and institutions. New Delhi: Pearson Education India.

Muradoglu, G., Berument, H., \& Metin, K. (1999). Financial Crisis and Changes in Determinants of Risk and Return: An Empirical Investigation of an Emerging Market (ISE). Multinational Finance Journal. Vol. 3(4): 223-252.

Morelli, D. (2002). The Relationship Between Conditional Stock Market Volatility and Conditional Macroeconomic Volatility: Empirical Evidence Based on UK Data. International Review of Financial Analysis. Vol. 11(1): 101-110.

Poon, S. H., \& Taylor, S. J. (1992). Stock Returns and volatility: an empirical study of the UK stock market. Journal of Banking \& Finance. Vol. 16(1): 37-59. doi: https://doi. org/10.1016/0378-4266(92)90077-D.

Pratama, Y. C., \& Azzis, A. (2017). Macroeconomic Variables, International Islamic Indices, and The Return Volatility in Jakarta Islamic Index. Al-Iqtishad: Jurnal Ilmu Ekonomi Syariah (Journal of Islamic Economics). Vol. 10(1): 171-188, doi: https://doi.org/10.15408/aiq. v10i1.5550.

Romli, N., Mohamad, A. A. S., \& Yusof, M. F. M. (2012). Volatility Analysis of FTSE Bursa Malaysia: Study of the Problems of Islamic Stock Market Speculation in The Period 2007 to 2010. African Journal of Business Management. Vol. 6 (29): 84-90.

Rose, P. S. (2000). Money and Capital Markets. $7^{\text {th }}$ Edition. New York: Irwin McGraw - Hill.

Saadaouia, A., \& Boujelbene, Y. (2015). Volatility Transmission Between Dow-Jones Stock Index and Emerging Islamic Stock Index: Case of Subprime Financial Crises. Journal of Emerging Economies and Islamic Research. Vol. 3(1): 1-9.

Shamsuddin, A. (2014). Are Dow Jones Islamic Equity Indices Exposed to Interest Rate Risk?. Economic Modelling. Vol. 39: 273-281. doi: https://doi.org/10.1016/j.econmod. 2014.03.007.

Tanjung, H. (2014). Volatility of Jakarta Islamic Index. Al-Iqtishad: Jurnal Ilmu Ekonomi Syariah (Journal of Islamic Economics). Vol. 6(2): 207-222. doi: https://doi.org/aiq.v6i2.1231.

Webley, P., Lewis, A., \& Mackenzie, C. (2001). Commitment Among Ethical Investors: An Experimental Approach. Journal of Economic Psychology. Vol. 22(1): 27-42. doi: https:// doi.org/10.1016/S0167-4870(00)00035-0.

Yusof, E. F. E. (2008). Are Islamic banks in Malaysia really 'Islamic'? MPRA Paper. No. 20901. Retrieved from: https://mpra.ub.uni-muenchen.de/20901/1/Are_Islamic_banks_in_ Malaysia_really_Islamic.pdf

Yusof, R. M., \& Majid, M. S. A. (2006). Policy and Persistence of Stock Returns Volatility: Conventional Versus Islamic Stock Market. Journal of International Business and Entrepreneurship. Vol. 12(1): 49-68.

Yusof, R. M., \& Majid, M.S.A. (2007). Stock Market Volatility Transmission in Malaysia: Islamic Versus Conventional Stock Market. JKAU: Islamic Economics. Vol. 20(2): 17-35.

Zakaria, Z., \& Shamsuddin, S. (2012). Empirical Evidence on the Relationship Between Stock Market Volatility and Macroeconomics Volatility in Malaysia. Journal of Business. Vol. 4(2): 61-71. 